\title{
Transfer of Micropolyspora rectivirgula (Krassilnikov and Agre 1964) Lechevalier, Lechevalier, and Becker 1966 to Faenia gen. nov.
}

\author{
V. P. KURUP ${ }^{1,2 *}$ AND NINA S. AGRE ${ }^{3}$
}

The Medical College of Wisconsin, Milwaukee, Wisconsin $53226^{1}$; Research Service, Veterans Administration Medical Center, Wood, Wisconsin 531932; and Institute of Biochemistry and Physiology of Microorganisms, Academy of Sciences, Pushchino, Moscow Region, Union of Soviet Socialist Republics ${ }^{3}$

Because Micropolyspora brevicatena, the type species of the genus Micropolyspora, has been removed from Micropolyspora to the genus Nocardia, we propose the name Faenia gen. nov. for the remaining species in the genus. The type species of this new genus is Faenia rectivirgula (Krassilnikov and Agre) comb. nov. The type strain of $F$. rectivirgula is VKM-A-810 $=$ INMU $683=$ ATCC 33515).

The genus Micropolyspora was described by Lechevalier et al. (18) for organisms that produce short chains of spores both on substrates and on aerial mycelia. Several species of this genus have been described by various authors (13). Recently, the type species, Micropolyspora brevicatena, was studied by different investigators who suggested placing it in the genus Nocardia $(3,12,13,19)$. Because the type species has been removed from the genus Micropolyspora, the name Micropolyspora becomes illegitimate according to Rule 37 a of the International Code of Nomenclature of Bacteria (16).

Of the several species included in the genus Micropolyspora, Micropolyspora angiospora and Micropolyspora internatus are on the Approved Lists of Bacterial Names (22), whereas others, such as "Micropolyspora viridinigra," "Micropolyspora rubrobrunea," "Micropolyspora caesia," "Micropolyspora thermovirida," and "Micropolyspora coerulea," are not on the Approved Lists. The names not on the Approved Lists have been used frequently by investigators and culture collections throughout the world. Recently, " $M$. viridinigra" and " $M$. rubrobrunea" (11) were considered to be members of the genus Excellospora by Agre and Guzeva (1). Kurup (13) found that these two species and $M$. angiospora (23) have type III cell walls, excluding them from Micropolyspora, which has type IV cell walls. " $M$. caesia" (7) and $M$. internatus (2) were shown to be closely related to members of the genus Saccharomonospora; hence, these two species were transferred to this genus as Saccharomonospora caesia and Saccharomonospora internatus (13).
The descriptions of " $M$. thermovirida" (9) and " $M$. coerulea" (21) indicate that these organisms are not typical members of the genus Micropolyspora. According to morphological studies of the only strain of " $M$. coerulea," strain TNA $4045^{\mathrm{T}}$ (type strain), this actinomycete is a typical representative of the genus Saccharomonospora. As a rule, cultures of this strain produce a great number of single spores and rarely produce short chains of two to four spores, which is also true of $S$. caesia (7) and $S$. internatus. The type strain of " $M$. thermovirida" (9) and all other strains conforming to it, have been lost.

The only two species remaining in the former genus Micropolyspora are Micropolyspora rectivirgula (10) and Micropolyspora faeni (4), both of which are included on the Approved Lists of Bacterial Names (22). Lechevalier et al. (17) reclassified Thermopolyspora rectivirgula as $M$. rectivirgula. However, on the Approved Lists, Prauser and Mamirov (20) were cited as the authors who coined the new combination. There has been much confusion in the literature regarding these two species, but our studies and those of Jones et al. (6) have shown that there is no difference between the two species morphologically, physiologically, immunologically, and in their phage susceptibilities $(5,6,8,13-15)$. Hence, these two species should be united.

$M$. rectivirgula was first described by Krassilnikov and Agre in 1964 (10) and has priority over M. faeni (4). According to Rule 42 of the International Code of Nomenclature of Bacteria (16), when two taxa of the same rank are united, the oldest legitimate name should be retained. Be- 
cause the type species of Micropolyspora is now known as Nocardia brevicatena, we propose a new genus, Faenia, to include $M$. rectivirgula as Faenia rectivirgula, which is also the type species.

Description of Faenia gen. nov. Faenia (Faen. i' a. L. n. faenum hay; L. f. pl. Faenia a genus of bacteria associated with hay) mycelium consists of branching aerial and substrate hyphae which are gram positive and 0.8 to $1.2 \mu \mathrm{m}$ in diameter. Spores are 0.7 to $1.5 \mu \mathrm{m}$ in diameter and are produced in chains of 2 to 15 on both aerial and substrate hyphae, usually on small sporophores. Spores grow slowly on most complex media at 35 to $60^{\circ} \mathrm{C}$. The cell walls are type IV and contain meso-diaminopimelic acid, arabinose, and galactose; no nocardomycolic acid has been detected.

The type species is $F$. rectivirgula (Krassilnikov and Agre) comb. nov. ( $\mathrm{rec}^{\prime}$ ti. vir. gu. la. L. adj. rectus straight; L. n. virgula twig; M. L. n. rectivirgula straight twig).

Description of Faenia rectivirgula comb. nov., emend. (i) Morphology. Branching aerial and substrate hyphae are 0.8 to $1.2 \mu \mathrm{m}$ in diameter. Spores are produced in chains of 2 to 15 on both aerial and substrate hyphae. Spores are smooth, spherical to ovate, and 0.7 to $1.5 \mu \mathrm{m}$ in diameter and are usually produced on sporophores. Spore chains are straight and do not form spirals. Young hyphae and spores are gram positive, whereas older hyphae and spores may be gram negative.

(ii) Cultural characteristics. Colonies on Trypticase soy agar, casein hydrolysate agar, and nutrient agar attain a diameter of 2 to $3 \mathrm{~mm}$ after 1 week of incubation at $50^{\circ} \mathrm{C}$. The color of the colonies varies from brownish yellow to pale orangeish yellow. Aerial hyphae appear as white tuftlike growth. No diffusible pigment is produced in any of these media.

(iii) Physiological characteristics. F . rectivirgula strains grow at 33 to $60^{\circ} \mathrm{C}$, with the best growth occurring between 50 and $55^{\circ} \mathrm{C}$. Most of the strains tolerate a $\mathrm{pH}$ range of 6.00 to 7.4. Galactose, glucose, lactose, mannose, glycerol, mannitol, and xylose are utilized as carbon sources; arabinose, maltose, rhamnose, sorbitol, and dulcitol are not. Esculin, arbutin, geltain, hypoxanthine, Tween 20 , and Tween 80 are hydrolyzed; adenine, starch, elastin, cellulose, chitin, casein, and tributyrin are not hydrolyzed. The strains produce deoxyribonuclease and catalase and reduce nitrate to nitrite. meso-Diaminopimelic acid, arabinose, and galactose are present in the cell walls.

(iv) Phage lysis. All strains of $F$. rectivirgula are lysed by actinophage MP (20) and by $\phi \mathrm{T}$ 150A (15).

(v) Type strain. The type strain is strain VKM-

\section{A-810 $(=$ INMI $683=$ ATCC 33515) $(10)$}

We thank H. A. Lechevalier for stimulating discussions, as well as the suggestion to use Faenia rectivirgula as the new combination.

V.P.K. acknowledges support by Public Health Service Asthma and Allergic Diseases Center grant AI19104 from the National Institutes of Health and by the Veterans Administration.

\section{LITERATURE CITED}

1. Agre, N. S., and L. N. Guzeva. 1975. New genus of actinomycetes: Excellospora gen. nov. Mikrobiologiya 44:518-523.

2. Agre, N. S., L. N. Guzeva, and L. A. Dorokhova. 1974 Micropolyspora internatus-a new species of Micropolyspora genus. Mikrobiologiya 43:679-685.

3. Collins, M. D., T. Pirouz, M. Goodfellow, and D. E. Minnikin. 1977. Distribution of menaquinones in actinomycetes and corynebacteria. J. Gen. Microbiol. 100:221230.

4. Cross, T., A. M. Maciver, and L. Lacey. 1968. The thermophilic actinomycetes in mouldy hay: Micropolyspora faeni sp. nov. J. Gen. Microbiol. 50:351-359.

5. Dorokhova, L. A., N. S. Agre, L. V. Kalakoutskii, and N. A. Krassilnikov. 1970. A study on morphology of two cultures belonging to the genus Micropolyspora. Mikrobiologiya 39:95-100.

6. Jones, M. P. A., A. J. McCarthy, and T. Cross. 1979. Taxonomic and serological studies of Micropolyspora faeni and Micropolyspora strains from soil bearing the specific epithet rectivirgula. J. Gen. Microbiol. 115:343354.

7. Kalakoutskii, L. V. 1964. A new species of the genus Micropolyspora-Micropolyspora caesia n. sp. Mikrobiologiya 33:858-862.

8. Kalakoutskii, L. V., N. S. Agre, and N. A. Krassilnikov. 1968. A comparative study on some oligosporic actinomycetes. Hind. Antibiot. Bull. 10:254-268.

9. Kosmachev, A. E. 1964. A new thermophilic actinomycete, Micropolyspora thermovirida $\mathrm{n}$. sp. Mikrobiologiya 33:267-269.

10. Krassilnikov, N. A., and N. S. Agre. 1964. On two new species of Thermopolyspora. Hind. Antibiot. Bull. 6:97107.

11. Krassilnikov, N. A., N. S. Agre, and G. I. El-Reghistan. 1968. New thermophilic species of the genus Micropolyspora. Mikrobiologiya 37:1065-1072.

12. Kurup, V. P. 1980 . Micropolyspora brevicatena. A member of the genus Nocardia. Actinomycetes 15:208-210.

13. Kurup, V. P. 1981. Taxonomic study of some members of Micropolyspora and Saccharomonospora. Microbiologica 4:249-259

14. Kurup, V. P., and J. N. Fink. 1979. Antigens of Micropolyspora faeni strains. Int. Arch. Allergy Appl. Immunol. 60:140-147.

15. Kurup, V. P., and R. J. Heinzen. 1978. Isolation and characterization of actinophage of Thermoactinomyces and Micropolyspora. Can. J. Microbiol. 24:794-797.

16. Lapage, S. P., P. H. A. Sneath, E. F. Lessel, V. B. D. Skerman, H. P. S. Seeliger, and W. A. Clark (ed.) 1975. International code of nomenclature of bacteria. 1975. Revision. American Society for Microbiology, Washington, D.C.

17. Lechevalier, H. A., M. P. Lechevalier, and B. Becker. 1966. Comparison of the chemical composition of cell walls of nocardiae with that of other actinomycetes. Int. J. Syst. Bacteriol. 16:151-160.

18. Lechevalier, H. A., M. Solotorovsky, and C. I. McDurmont. 1961. A new genus of the actinomycetales: Micropolyspora gen. nov. J. Gen. Microbiol. 26:11-18.

19. Minnikin, D. E., M. D. Collins, and M. Goodfellow. 1976. Menaquinone patterns in the classification of nocardioform and related bacteria, p. 85-90. In M. Mordarski, W. 
Kurylowicz, and J. Jeljaszewicz (ed.), Nocardia and Streptomyces. Gustav Fischer Verlag, Stuttgart.

20. Prauser, H., and S. Momirova. 1970. Phagensensibilitat, Zellwand-Zusammensetzung und Taxonomie einiger Thermophiler Actinomyceten. Z. Allg. Mikrobiol. 10:219222.

21. Preobrazhenskaya, T. P., R. S. Ukholina, N. P. Nechaeva, V. A. Filicheva, G. V. Gavrilina, M. K. Kudinova, V. N. Borisova, N. M. Patukhova, I. N. Kovsharova, V. V.
Proshlyakova, and O. K. Rossolimo. 1973. A new species of Micropolyspora and its antibiotic properties. Antibiotiki 18:963-970.

22. Skerman, V. B. D., V. McGowan, and P. H. A. Sneath (ed.). 1980. Approved lists of bacterial names. Int. J. Syst. Bacteriol. 30:225-420.

23. Zhukova, R. A., V. A. Tsyganov, and V. M. Morozov. 1968. A new species of Micropolyspora: Micropolyspora angiospora sp. nov. Mikrobiologiya 37:724-728. 